\title{
Reduction of Rhizoctonia Bare Patch in Wheat with Barley Rotations
}

\author{
W. F. Schillinger, Department of Crop and Soil Sciences, Washington State University, Dryland Research Station, \\ P.O. Box B, Lind 99341; and T. C. Paulitz, Root Disease and Biological Control Unit, United States Department of \\ Agriculture-Agricultural Research Service, Washington State University, Pullman 99164-6430
}

\begin{abstract}
Schillinger, W. F., and Paulitz, T. C. 2006. Reduction of Rhizoctonia bare patch in wheat with barley rotations. Plant Dis. 90:302-306.

Rhizoctonia bare patch caused by Rhizoctonia solani AG-8 is a major fungal root disease in notill cropping systems. In an 8-year experiment comparing various dryland no-till cropping systems near Ritzville, WA, Rhizoctonia bare patch first appeared in year 3 and continued unabated through year 8. Crop rotation had no effect on bare patch during the first 5 years. However, from years 6 to 8, both soft white and hard white classes of spring wheat (Triticum aestivum L.) grown in a 2-year rotation with spring barley (Hordeum vulgare L.) had an average of only $7 \%$ of total land area with bare patches compared with $15 \%$ in continuous annual soft white wheat or hard white wheat (i.e., monoculture wheat). In years 6 to 8 , average grain yield of both soft white wheat and hard white wheat were greater $(P<0.001)$ when grown in rotation with barley than in monoculture. Although both classes of wheat had less bare patch area and greater grain yield when grown in rotation with barley, monoculture hard white wheat was more severely affected by Rhizoctonia than soft white wheat. Soil water levels were higher in bare patches, indicating that roots of healthy cereals did not grow into or underneath bare patch areas. This is the first documentation of suppression of Rhizoctonia bare patch disease in low-disturbance notill systems with rotation of cereal crops.
\end{abstract}

Rhizoctonia bare patch and root rot is a major disease in no-till cereals in Australia (11) and the Pacific Northwest (PNW) (14). No-till is defined as planting directly into residue of the previous crop without tillage that mixes or stirs soil prior to planting. Rhizoctonia solani AG-8, the causal agent, attacks seminal and crown roots, pruning away root tips and rotting the root cortex, resulting in patches of dead or stunted plants up to several meters in diameter in the field.

Farmers in the PNW are increasingly interested in no-till to reduce soil erosion, improve soil structure and organic matter, and reduce fuel inputs. The traditional crop rotation in the low-precipitation (less than $300 \mathrm{~mm}$ annual) zone of the inland PNW is winter wheat-summer fallow, where only one crop is grown every 2 years. Intensive tillage during summer fallow buries excessive quantities of residue, reduces soil cloddiness and surface roughness, and is the cause of recurrent wind erosion and air quality problems (12). Unfortunately, Rhizoctonia bare patch increases when tillage is eliminated $(16,19,20)$, and the disease has become a major limiting factor to the adoption of no-till technology.

Corresponding author: W. F. Schillinger

E-mail: schillw@wsu.edu

Accepted for publication 3 October 2005.

DOI: 10.1094/PD-90-0302

(C) 2006 The American Phytopathological Society
Other than tillage, there are few management options for control of Rhizoctonia spp. Reduction of the green bridge carryover of inoculum from volunteer and grassy weeds is achieved with timely application of glyphosate ( $N$-[phosphonomethyl] glycine) or other burn-down herbicides at least 2 weeks before planting (23). Soil disturbance in the seed row by aggressive hoe-type no-till drill openers also may help (19). Fungicide seed treatments may provide limited protection for germinating seed but do not protect roots or increase yield in patchy fields (4).

Crop rotation with a broadleaf or nonhost crop is a management strategy that works well for some cereal soilborne pathogens such as take-all (3) and sharp eyespot caused by $R$. cerealis $(1,27)$. However, in addition to cereals, $R$.. solani AG-8 attacks pulse and oilseed crops such as pea (Pisum sativum L.), canola (Brassica napus and B. campestris), yellow mustard (B. hirta Moench), safflower (Carthamus tinctorius L.), sunflower (Helianthus annuus L.), lentil (Lens culinaris Medik.), and chickpea (Cicer arietinum L.). Bare patches also occur in these crops $(2,20)$.

Few studies have quantified benefits of crop rotation on control of Rhizoctonia spp. In Australia, King (8) found less $R$. solani infection on roots of wheat grown after grain legumes compared with after grass pastures or wheat. Rovira (20) reported no effect of rotation on root infection, but found less patch area in wheat after medic or pea compared with wheat after grass pasture or wheat after wheat.
Roget (18) also observed a long-term (7year) trend of greater patch area in wheat after pasture compared with wheat after pea or medic, although the statistical differences within a given year often were not significant. During the first 5 years of conversion from conventional tillage to no-till in eastern Washington, crop rotation had no effect on the Rhizoctonia bare patch area of spring wheat (2). The present study was conducted at the same experiment site as that reported by Cook et al. (2).

The objective of our study was to determine the long-term feasibility of annual notill cropping with diverse rotations in a 300$\mathrm{mm}$ precipitation zone in eastern Washington. This article reports new findings on reduction of Rhizoctonia bare patch area and increased grain yield for two classes of wheat grown in annual monoculture and in a 2-year wheat-barley rotation.

\section{MATERIALS AND METHODS}

Field layout and treatments. An 8-year field study of no-till annual cropping systems was conducted from 1997 to 2004 at the Ron Jirava farm near Ritzville, Adams County, WA. The soil at the experiment site is a Ritzville silt loam (coarse-silty, mixed, superactive, mesic Calcidic Haploxerolls). Soil is $>2 \mathrm{~m}$ deep with no rocks or restrictive layers and slopes are $<1 \%$. Thirty-year average annual precipitation for the site is $301 \mathrm{~mm}$ (Table 1).

Although numerous crop rotations were evaluated for soil water dynamics, weed ecology, root disease (2), and economics (7) during phase I (1997-2000) and phase II (2001-04) of the experiment, this article reports findings from only four croprotation treatments. These treatments were: (i) continuous annual soft white spring wheat, (ii) a 2-year soft white spring wheat-spring barley rotation, (iii) continuous annual hard white spring wheat, and (iv) a 2-year hard white spring wheatspring barley rotation. The continuous soft white wheat and soft white wheat-barley rotations were in existence for the entire 8 years and each crop of the rotation was grown each year. Experimental design was a randomized complete block with four replications and 20-by-150-m plots. In 2001, the soft white wheat and soft white wheat-barley were split along the long axis to introduce hard white wheat (previously soft white wheat) and hard white wheat-barley (previously soft white wheat-barley). Thus, the plot size was 10 by $150 \mathrm{~m}$ from 2001 to 2004 . The cultivars 
used were Alpowa soft white wheat, 377S hard white wheat, and Baronesse barley.

Glyphosate herbicide was applied 2 to 4 weeks before planting at $0.43 \mathrm{~kg}$ acid equivalent (ae) ha ${ }^{-1}$ to control weeds and disease green bridge (23). Planting was conducted during a 2-day period during the last week in March or first week of April in all years. In the first 3 years (1997 to 1999), all plots were planted and fertilized in one pass directly into the undisturbed soil and residue left by the previous crop using the cooperating farmer's Flexi-Coil 6000 air-delivery no-till drill equipped with Barton II dual-disk openers on 19-cm row spacing. From 2000 to 2004, all plots were planted and fertilized in one pass using a custom-built no-till drill equipped with Cross-slot notched-coulter openers on $20-\mathrm{cm}$ row spacing. Both drills cause little soil disturbance and provide simultaneous and precision placement of seed and fertilizer, with the fertilizer placed beneath and slightly to one side of the seed. Seeding rate over the years was held constant at 78 $\mathrm{kg} \mathrm{ha}^{-1}$ for soft white wheat, hard white wheat, and barley. Solution $32\left(\mathrm{NH}_{4} \mathrm{NO}_{3}+\right.$ urea) provided the base for liquid fertilizer to supply an average of $39 \mathrm{~kg}$ of N, $8 \mathrm{~kg}$ of $\mathrm{P}$ (aqueous solution of $\mathrm{NH}_{4} \mathrm{H}_{2} \mathrm{PO}_{4}$ ) and 11 $\mathrm{kg}$ of $\mathrm{S}$ (aqueous solution of $\left(\mathrm{NH}_{4}\right)_{2} \mathrm{~S}_{2} \mathrm{O}_{3}$ ) $\mathrm{ha}^{-1}$. The quantity of available soil water and residual $\mathrm{N}, \mathrm{P}$, and $\mathrm{S}$ was measured in all rotations in mid-March each year to determine fertilizer needs based on a yield goal. Fertilizer rate was always the same for all treatments in all years.

Between the tillering and jointing phases of growth of soft white wheat, hard white wheat, and barley, in-crop broadleaf weeds were controlled with 2,4-D at $0.7 \mathrm{~kg}$ ae $\mathrm{ha}^{-1}$ plus Harmony Extra (50\% thifensulfuron $+25 \%$ tribenuron) herbicide at $0.9 \times 10^{-2}$ liter active ingredient (ai) $\mathrm{ha}^{-1}$ from 1997 to 2000, and with 2,4-D at 0.55 $\mathrm{kg}$ ae $\mathrm{ha}^{-1}$ plus dimethylamine salt of dicamba herbicide at $0.13 \mathrm{~kg}$ ae ha- $\mathrm{h}^{-1}$ from 2001 to 2004. Russian thistle (Salsola spp.), a major broadleaf weed of springplanted crops (21), was present at time of grain harvest in late July in 6 of 8 years.
When present, Russian thistle was controlled with paraquat at $0.42 \mathrm{~kg}^{\text {ai ha }}{ }^{-1}$ plus diuron at $0.21 \mathrm{~kg}$ ai ha ${ }^{-1}$ applied 7 days after grain harvest.

Soil water. Soil water content in a 1.8$\mathrm{m}$ soil profile was measured in continuous soft white wheat and both phases of soft white wheat-barley each spring before planting and again after grain harvest from 1997 to 2000. Soil volumetric water content in the 0 - to $0.3-\mathrm{m}$ depth was determined from two 0.15 -m core samples using gravimetric procedures and in the 0.3to $1.8-\mathrm{m}$ depth in $0.15-\mathrm{m}$ increments by neutron attenuation (5). Due to lack of soil water differences between treatments from 1997 to 2000 and constraints of labor and time, soil water content was measured only in continuous soft white wheat from 2001 to 2004. Precipitation was measured on site during all years with a computerized weather station.

In 2003 and 2004, soil water content was measured within and outside of Rhizoctonia patches in continuous soft white wheat to determine whether soil water was stranded in the bare patches or if wheat roots extracted water from within patches. Using soil water measurement procedures described above (5), access tubes were placed in five locations: (i) 1.8 $\mathrm{m}$ inside a patch, (ii) $1.2 \mathrm{~m}$ inside a patch, (iii) $0.6 \mathrm{~m}$ inside a patch, (iv) at the border of healthy wheat and the patch area, and (v) $3.0 \mathrm{~m}$ outside the patch in healthy wheat. Tubes were installed in one large (i.e., greater than 4-m-diameter) bare patch in each of the four continuous soft white wheat replications. Soil water was measured in early June, as soon as bare patch areas could be clearly delineated, and again in mid- to late July near the time of grain harvest.

Measurement of Rhizoctonia bare patch area. Patches first appeared during year 3 of the experiment in 1999 and were present every year thereafter. The location, size, and area of patches were determined with a Pathfinder Pro XR global positioning system (GPS) equipped with mapping software (Fig. 1). Measurements were obtained by circling each clearly visible Rhizoctonia patch with the backpackmounted GPS mapping unit (Fig. 1). Rhizoctonia bare patch areas were mapped every year from 1999 to 2004, except in 2001 when drought made it difficult to discern the border areas between Rhizoctonia bare patches and severely waterstressed wheat and barley.

Grain yield. Grain yield was determined in late July or early August by harvesting the grain from plants in a swath through each 150-m-long plot with a commercial combine with 6.1-m-wide cutting platform and auguring grain into a weigh wagon.

Statistical analysis. An analysis of variance was conducted for total water content in the $1.8-\mathrm{m}$ soil profile, Rhizoctonia bare patch area, and grain yield. Treatment means were considered significantly different at $P<0.05$. The Bonferroni method was used to control the experimentwise error rate for multiple comparisons.

\section{RESULTS}

Precipitation, available soil water, and soil water use by wheat and barley. Crop-year (1 September to 31 August) precipitation ranged from 188 to $486 \mathrm{~mm}$ and averaged $262 \mathrm{~mm}$ over the 8-year period. Less than average (i.e., $<301 \mathrm{~mm}$ ) precipitation occurred in 7 of 8 crop years (Table 1). Precipitation during the 2002, 2003, and 2004 crop years was 242, 269, and $188 \mathrm{~mm}$, respectively.

Plant available soil water for continuous soft white wheat at time of planting in late March or early April ranged from 81 to $257 \mathrm{~mm}$ and averaged $134 \mathrm{~mm}$ over the 8 years (Table 1). There were no differences in soil water between continuous soft white wheat and either phase of the soft white wheat-barley rotation from 1997 to 2000 (data not shown). Soft white wheat and barley extracted soil water to an average content of 6 to $7 \%$ by volume in the $1.8-\mathrm{m}$ soil profile by time of grain harvest in July. Over-winter precipitation storage efficiency (i.e., the percentage of precipita-

Table 1. Plant available soil water in the 1.8-m soil profile in the continuous annual soft white spring wheat treatment at time of sowing in late March or early April, September-through-March precipitation, growing season precipitation, and 12-month total precipitation during the 8-year experiment as well as 30-year average precipitation near Ritzville, WA

\begin{tabular}{|c|c|c|c|c|c|c|c|c|}
\hline \multirow[b]{2}{*}{ Year } & \multirow[b]{2}{*}{ Soil water ${ }^{\mathbf{a}}$} & \multicolumn{7}{|c|}{ Precipitation $(\mathbf{m m})$} \\
\hline & & September-March & April & May & June & July & August & 12-month total \\
\hline 1997 & 257 & 389 & 35 & 34 & 20 & 6 & 2 & 486 \\
\hline 1998 & 133 & 195 & 7 & 36 & 12 & 25 & 7 & 282 \\
\hline 1999 & 122 & 170 & 6 & 4 & 9 & 2 & 8 & 199 \\
\hline 2000 & 123 & 164 & 18 & 13 & 24 & 11 & 0 & 230 \\
\hline 2001 & 81 & 144 & 19 & 22 & 5 & 2 & 12 & 204 \\
\hline 2002 & 115 & 182 & 12 & 21 & 19 & 7 & 1 & 242 \\
\hline 2003 & 146 & 221 & 31 & 12 & 2 & 0 & 3 & 269 \\
\hline 2004 & 96 & 126 & 20 & 34 & 1 & 0 & 7 & 188 \\
\hline 8-year average & 134 & 199 & 18 & 22 & 11 & 7 & 5 & 262 \\
\hline 30 -year averageb & $\ldots$ & 212 & 23 & 26 & 18 & 11 & 11 & 301 \\
\hline
\end{tabular}

${ }^{a}$ Available soil water for cereals was calculated as average volumetric soil water (\%) in the $1.8-\mathrm{m}$ soil profile minus $6.0 \%$.

b The 30-year (1974 to 2004) average precipitation is for the city of Ritzville located $7 \mathrm{~km}$ east of the experiment site. 
tion that occurred from grain harvest until late March that was stored in the soil) averaged $67 \%$ for continuous soft white wheat during the 8 years.

Rhizoctonia bare patch area. Rhizoctonia bare patch first appeared in 1999 during year 3 of the experiment and continued through year 8 . Rhizoctonia patches were clearly apparent in safflower, yellow mustard, wheat, and barley regardless of crop rotation sequence (2). The percent area of Rhizoctonia bare patch was not affected by crop or crop rotation in 1999 and 2000; however, beginning in 2002 and continuing in 2003 and 2004, significantly

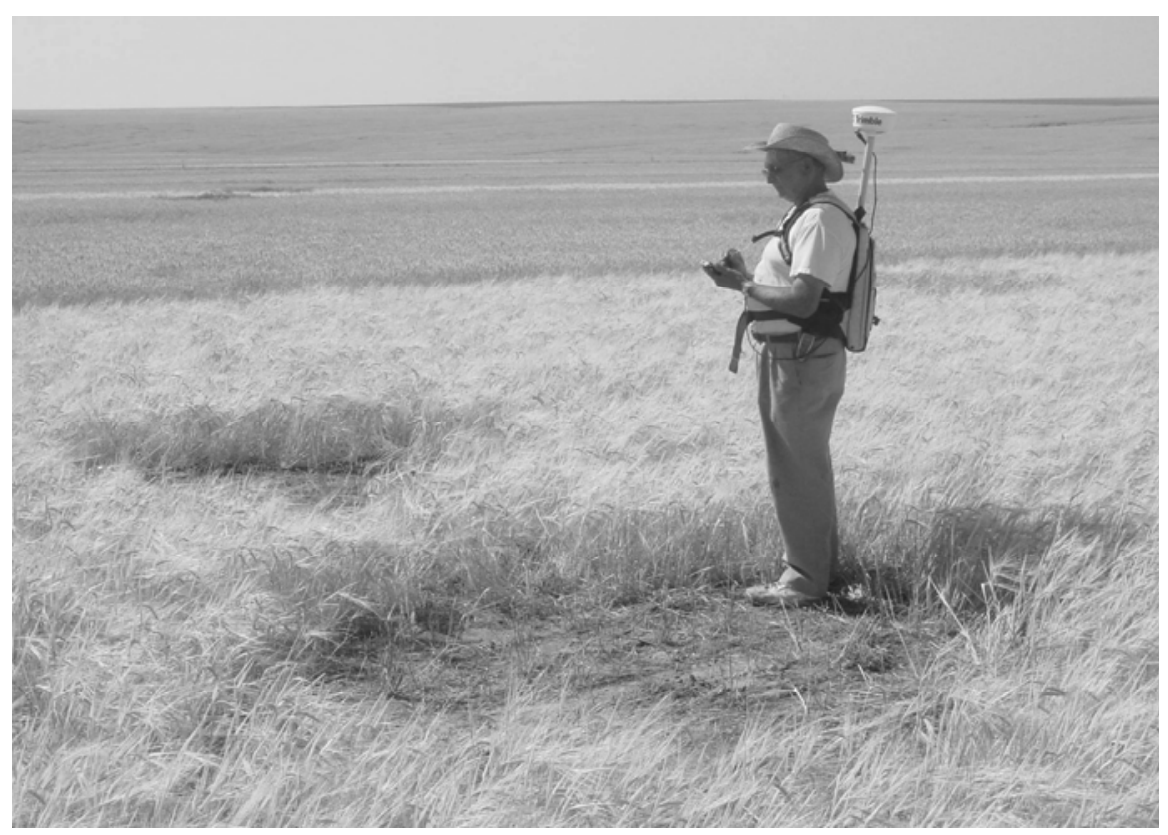

Fig. 1. Rhizoctonia bare patches, seen here in barley, were mapped using a backpack-mounted global positioning unit.

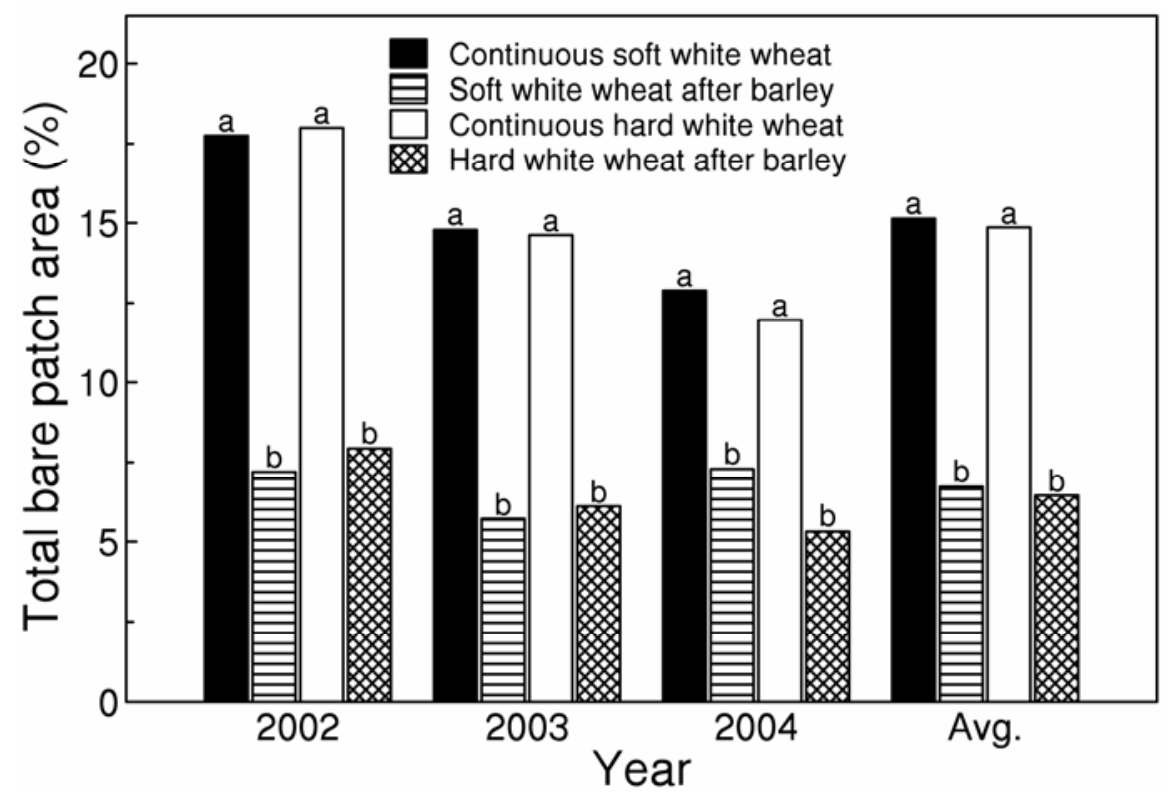

Fig. 2. Rhizoctonia bare patch area as a percentage of total plot area in continuous annual soft white wheat and continuous annual hard white wheat compared with soft white wheat and hard white wheat grown in a 2-year rotation with spring barley. Within-year and 3-year average means followed by the same letter are not significantly different at $P<0.05$.
2004) average for total barley plot area with bare patch was $11.2 \%$ following soft white wheat and $8.7 \%$ following hard white wheat. Bare patches in barley generally were in the same location as found in the previous wheat crop, although some patches increased in size, other patches shrank, and some new patches formed. This bare patch pattern is similar to reports from the earlier years of this long-term experiment (2). There were no significant differences in bare patch area in barley following soft white or hard white wheat in any year or when averaged over the 3 years.

Soil water is stranded in bare patch areas. Healthy soft white wheat growing 3 $\mathrm{m}$ from the nearest bare patch had used significantly more soil water than wheat on the border of a patch on both early June and mid- to late-July measurement dates in 2003 and 2004 (Fig. 3). Soil water content at the border of patches was less than from locations within the patch. Soil water content measured from access tubes located $0.6,1.2$, and $1.8 \mathrm{~m}$ inside the bare patches was always the same on all dates during both years (Fig. 3).

Grain yield. From 2002 to 2004, grain yield of soft white wheat after barley was greater than monoculture soft white wheat in 2 of 3 years as well as the 3-year average (Fig. 4). There were no significant differences in grain yield between hard white wheat after barley compared with monoculture hard white wheat in 2002 and 2003; however, in 2004 (and in the 3-year average), monoculture hard white wheat had the lowest grain yield of all treatments (Fig. 4). There was a highly significant $(P$ $<0.001$ ) year-treatment interaction for wheat grain yield. Overall grain yields trended higher in 2004 (Fig. 4) even though only $188 \mathrm{~mm}$ of precipitation occurred during the crop year (Table 1). We attribute this phenomenon to timely and generous rain showers that totaled $34 \mathrm{~mm}$ during May 2004 (Table 1).

Barley grain yield following soft white wheat and hard white wheat averaged 1,939 and $1,979 \mathrm{~kg} \mathrm{ha}^{-1}$, respectively, during the 3 years. There were no significant differences in barley grain yield between treatments in any year or when averaged over the 3 years.

\section{DISCUSSION}

This study provides the first documentation that barley provides a positive longterm rotation effect on wheat compared with monoculture wheat. There were no beneficial effects on soft white wheat grain yield when grown in rotation with safflower, yellow mustard, or barley during the first 5 years of the cropping systems experiment (2). This was explained by the wide host range of $R$. solani AG-8 that attacks safflower, yellow mustard, barley, pea, lentil, and canola (2). However, starting in year 6 , a rotation effect was seen 
with barley in 2-year soft white wheatbarley and hard white wheat-barley rotations. This is surprising, because barley is very susceptible to $R$. solani AG-8. In fact, barley often shows greater stunting than wheat, a phenomenon also seen with $R$. oryzae (15). A rotation effect usually is seen with a nonhost crop. For example, take-all caused by Gaeumannomyces graminis var. trtici is controlled by rotation with a nonhost broadleaf crop like pea (3). The rotation phenomenon observed in this study may be unique to long-term no-till cropping. During the first 2 years of transition from conventional-till to no-till in a soft white wheat-barley rotation near Garfield, WA, no differences in damage or yield loss were measured between tillage methods (22). However, in year 3 and 4, significant grain yield losses occurred in no-till soft white wheat, accompanied by increased activity of $R$. solani. Thus, the beneficial effect of the barley rotation was not seen at the Garfield location during the early transition to no-till.

What are some possible explanations for this rotation effect? There was no difference in water use between barley and soft white wheat, based on multiple-year measurements taken at the experimental site (W. F. Schillinger, unpublished). Barley is a less favorable host for lesion nematodes (Pratylenchus neglectus and P. thornei) than either soft white wheat or hard white wheat (6); however, DNA testing in fall 2004 did not detect these nematodes (data not shown). One possible explanation is a suppressive microbial effect. Barley may select for microbes that are antagonistic to Rhizoctonia spp. Host genotype can affect beneficial bacteria, such as Pseudomonas spp., which are involved in the biological control of fungal soilborne pathogens (25). Different genotypes of phloroglucinolproducing Pseudomonas fluorescens have different preferences for colonizing the roots of pea and wheat $(9,17)$. In fact, a susceptible host is a prerequisite for the establishment of a monoculture decline such as take-all decline. The antagonistic Pseudomonas spp. multiply in the lesions on the root caused by pathogen infection and produce antifungal compounds such as phloroglucinol and phenazine which inhibit the spread of the pathogen in the root (28). Intact soil cores were taken from the centers and outside of these patches from our study site, and were planted with five crops of barley over a 9-month period in the greenhouse. Initially, stunting was observed in most of the cores from the patch centers compared with cores from outside of the patches. However, by the end of the experiment, many cores from the center no longer showed stunting, suggesting that the patches had become suppressive (13). Other researchers have found evidence of suppression of Rhizoctonia spp. after long-term monoculture of wheat under direct seed conditions $(10,18)$;

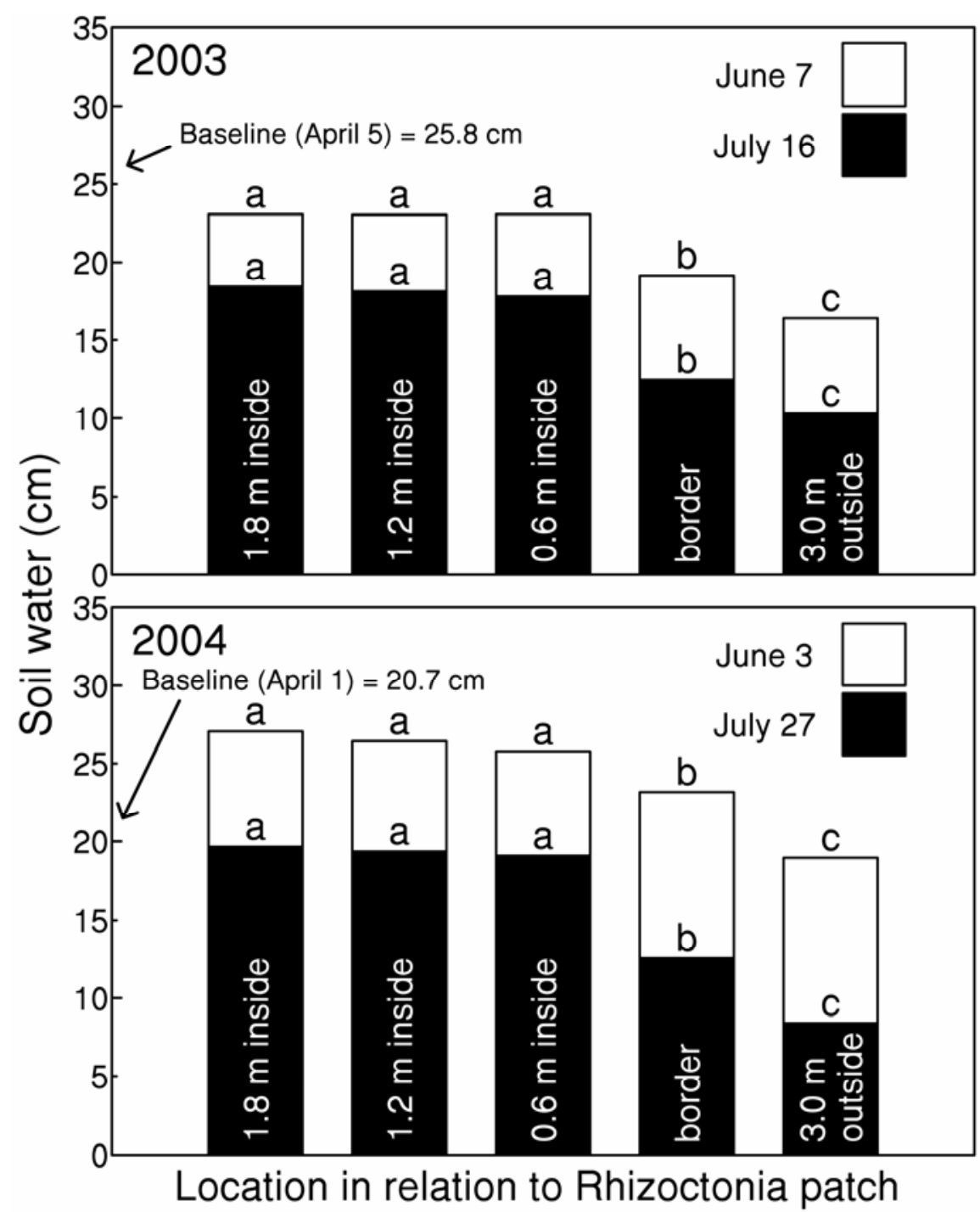

Fig. 3. Total soil water content in the $1.8-\mathrm{m}$ soil profile in early June and mid- to late July 2003 and 2004 as affected by the location inside, at the border, and outside of Rhizoctonia bare patches. Means for each sampling date followed by the same letter are not significantly different at $P<0.05$.

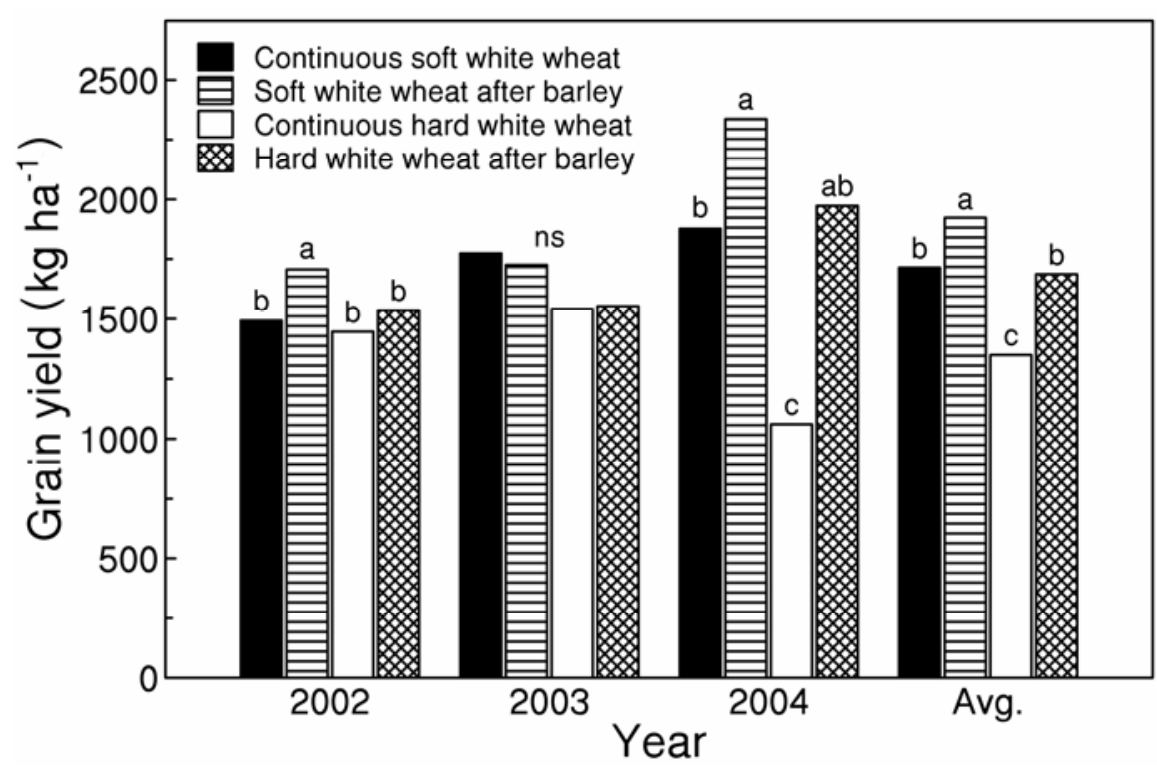

Fig. 4. Grain yield of continuous annual soft white wheat and continuous annual hard white wheat compared with soft white wheat and hard white wheat grown in a 2-year rotation with spring barley. Withinyear and 3-year average means followed by the same letter are not significantly different at $P<0.05$. 
however, no specific mechanism of suppression has been identified.

Another possibility for the rotation benefit is that barley leaves less inoculum in the soil for the subsequent crop. $R$. solani AG-8 survives in living roots and does not readily form other survival structures such as sclerotia (14). Barley roots may decompose faster than wheat roots, leaving less inoculum for the following year.

A difference was observed between two wheat classes in the disease response to Rhizoctonia spp. Paulitz et al. (15) demonstrated that the spring wheat cv. Scarlet was more damaged by isolates of $R$. oryzae than the winter wheat cv. Madsen. Smith et al. (24) observed that hard white wheat cv. $377 \mathrm{~S}$ was more susceptible to $R$. solani AG- 8 than the soft white wheat cv. Alpowa in greenhouse assays. In inoculated field tests, there were differences in susceptibility among genotypes of spring wheat, but none were resistant. The hard white wheat cv. 377S was not tested, but the soft white wheat cv. Alpowa did not exhibit significant grain yield differences when grown in high versus low inoculum (26). Although our study confirms differences in susceptibility between these two classes of spring wheat, generalizations to entire wheat classes cannot be made without further testing of a range of cultivars.

In Mediterranean climate regions like the PNW, the quantity of water stored in the soil during the winter months is an important determinant of grain yield. If large patches are devoid of plants, can surrounding plant roots grow into these areas and utilize this water, thus compensating for yield loss from Rhizoctonia spp.? Our results show that soft white wheat roots do not extract soil water from within Rhizoctonia bare patches. The uniform decline in soil water content within the patches between early June and mid- to late July probably was due to evaporation because wheat plants were severely stunted or dead by the June measurement. Because soft white wheat did not extract soil water even from just $0.6 \mathrm{~m}$ inside the border, it appears that roots from healthy soft white wheat at the border do not extend into patches. Therefore, soil water within bare patches is truly stranded and grain yield reduction corresponding to the percentage of bare patch area can be expected.

Despite the fact that all rotation crops are susceptible to $R$. solani AG-8, a positive rotation effect of barley was measured on two classes of spring wheat in years 6 , 7 , and 8 of the study. Further research will focus on elucidating the mechanism behind this rotation phenomenon by measuring changes in microbial communities between the two rotations. In addition, other no-till management practices may possibly affect Rhizoctonia bare patch, including chemical fallow (to deny a host) and high disturbance hoe-type grain drill openers to provide a tillage zone around the developing seedling.

\section{LITERATURE CITED}

1. Colbach, N., Lucas, P., Cavelier, N., and Cavelier, A. 1997. Influence of cropping system on sharp eyespot in winter wheat. Crop Prot. 16:415-422.

2. Cook, R. J., Schillinger, W. F., and Christensen, N. W. 2002. Rhizoctonia root rot and takeall of wheat in diverse direct-seed spring cropping systems. Can. J. Plant Pathol. 24:349-358.

3. Cook, R. J., and Veseth, R. J. 1991. Wheat Health Management. American Phytopathological Society Press, St. Paul, MN.

4. Cook, R. J., Weller, D. M., El-Banna, A.Y., Vakoch, D., and Zhang, H. 2002. Yield responses of direct-seed wheat to fungicide and rhizobacteria treatments. Plant Dis. 87:780784.

5. Gardner, W. H. 1986. Water content. Pages 493-544 in: Methods of Soil Analysis. Part 1. Agron. Monogr. 9. A. Klute, ed. ASA and SSSA, Madison, WI.

6. Hollaway, G. J., Taylor, S. P., Eastwood, R. F., and Hunt, C. H. 2000. Effect of field crops on density of Pratylenchus in southeastern Australia; Part 2: P. thornei. J. Nematol. 32:600608.

7. Juergens, L. A., Young, D. L., Schillinger, W. F., and Hinman, H. R. 2004. Economics of alternative no-till spring crop rotations in Washington's wheat-fallow region. Agron. J. 96:154-158.

8. King, P. M. 1984. Crop and pasture rotations at Coonalpyn, South Australia: Effects on soilborne diseases, soil nitrogen and cereal production. Aust. J. Exp. Agric. Anim. Husb. 24:555-564.

9. Landa, B. B., Mavrodi, O. V., Raaijmakers, J. M., McSpadden Gardener, B. B., Thomashow, L. S., and Weller, D.M. 2002. Differential ability of genotypes of 2, 4diacetylphloroglucinol-producing Pseudomonas fluorescens strains to colonize the roots of pea plants. Appl. Environ. Microbiol. 68:32263237.

10. MacNish, G. C. 1988. Changes in take-all (Gaeumannomyces graminis var. tritici), Rhizoctonia root rot (Rhizoctonia solani) and soil $\mathrm{pH}$ in continuous wheat with annual applications of nitrogenous fertilizer in Western Australia. Aust. J. Exp. Agric. 28:333-341.

11. MacNish, G. C., and Neate, S. M. 1996. Rhizoctonia bare patch of cereals: An Australian perspective. Plant Dis. 80:965-971.

12. Papendick, R. I. 2004. Farming with the wind II: Wind erosion and air quality control on the Columbia Plateau and Columbia Basin. Special Report by the Columbia Plateau $\mathrm{PM}_{10}$ Project. Rep. XB 1042. Wash. Agric. Exp. Stn., Pullman.

13. Paulitz, T. C., Schillinger, W. F., and Cook, R.
J. 2003. Greenhouse studies of Rhizoctonia bare patch disease in soil cores from directseeded fields. (CD-ROM). Am. Soc. Agron. Annu. Meet., ASA, CSSA, and SSSA Abstr. Denver, CO.

14. Paulitz, T. C., Smiley, R. W., and Cook, R. J. 2002. Insights into the prevalence and management of soilborne cereal pathogens under direct seeding in the Pacific Northwest, USA Can. J. Plant Pathol. 24:416-428.

15. Paulitz, T. C., Smith, J. D., and Kidwell, K. K. 2003. Virulence of Rhizoctonia oryzae on wheat and barley cultivars from the Pacific Northwest. Plant Dis. 87:51-55.

16. Pumphrey, F. V., Wilkins, D. E., Hane, D. C., and Smiley, R. W. 1987. Influence of tillage and nitrogen fertilizer on Rhizoctonia root rot (bare patch) of winter wheat. Plant Dis. 71:125-127.

17. Raaijmakers, J. M., and Weller, D. M. 2001 Exploiting genotypic diversity of 2,4diacetylphloroglucinol-producing Pseudomonas spp.: Characterization of superior rootcolonizing $P$. fluorescens strain Q8r1-96. Appl Environ. Microbiol. 67:2545-2554.

18. Roget, D. K. 1995. Decline in root rot (Rhizoctonia solani AG-8) in wheat in a tillage and rotation experiment at Avon, South Australia. Aust. J. Exp. Agric. 35:1009-1013.

19. Roget, D. K., Neate, S. M., and Rovira, A. D. 1996. The effect of sowing point design and tillage practice on the incidence of Rhizoctonia root rot, take-all, and cereal cyst nematode. Aust. J. Exp. Agric. 36:683-693.

20. Rovira, A. D. 1986. Influence of crop rotation and tillage on Rhizoctonia bare patch of wheat Phytopathology 76:669-673.

21. Schillinger, W. F., and Young, F. L. 2000. Soil water use and growth of Russian thistle after wheat harvest. Agron. J. 92:167-172.

22. Schroeder, K. L. 2004. The dynamics of root diseases of wheat and barley in the transition from conventional tillage to direct seeding. $\mathrm{Ph} . \mathrm{D}$. dissertation, Washington State University, Pullman.

23. Smiley, R. W., Ogg, A. G., and Cook, R. J. 1992. Influence of glyphosate on severity of Rhizoctonia root rot and growth and yield of barley. Plant Dis. 76:937-942.

24. Smith, J. D., Kidwell, K. K., Evans, M. A., Cook, R. J., and Smiley, R. W. 2003. Assessment of spring wheat genotypes for disease reaction to Rhizoctonia solani AG 8 in controlled environment and no-till field conditions. Crop Sci. 43:694-700.

25. Smith, J. D., Kidwell, K. K., Evans, M. A., Cook, R. J., and Smiley, R. W. 2003. Evaluation of spring cereal grains and wild Triticum relatives for resistance to Rhizoctonia solani AG 8. Crop Sci. 43:701-709.

26. Smith, K. P., and Goodman, R. M. 1999. Host variation for interactions with beneficial plantassociated microbes. Annu. Rev. Phytopathol. 37:473-491.

27. Vilich, V. 1993. Crop rotation with pure stands and mixtures of barley and wheat to control stem and root rot diseases. Crop Prot. 12:373379.

28. Weller, D. M., Raaijmakers, J. M., McSpadden Gardener, B. B., and Thomashow, L. S. 2002. Microbial populations responsible for specific soil suppressiveness to plant pathogens. Annu. Rev. Phytopathol. 40:309-348. 